\title{
EFEK KO-KEMOTERAPI FRAKSI ETIL ASETAT AKAR PASAK BUMI DAN DOXORUBICIN TERHADAP PROLIFERASI DAN EKPRESI BAX JARINGAN PAYUDARA TIKUS SD
}

\section{CO-CHEMOTHERAPY EFFECTS OF ETHYL ACETATE FRACTION OF PASAK BUMI ROOTS AND DOXORUBICIN TOWARD PROLIFERATION AND BAX EXPRESSION ON SD RATS' BREAST TISSUE}

\author{
Tria Zakinah $^{\left.1^{*}\right)}$, Laela Hayu Nurani ${ }^{1}$, Sitarina Widyarini ${ }^{2}$ \\ ${ }^{1}$ Fakultas Farmasi Universitas Ahmad Dahlan, Jl. Prof. Dr. Soepomo, S.H., Janturan, Warungboto, \\ Umbulharjo, Daerah Istimewa Yogyakarta \\ ${ }^{2}$ Fakultas Kedokteran Hewan Universitas Gajah Mada, Jl. Fauna No. 2, Caturtunggal, Depok, \\ Kec. Sleman, Daerah Istimewa Yogyakarta
}

Received May 27, 2016; Accepted November 11, 2016

\begin{abstract}
The use of co-chemotherapy agent was needed since there were some toxicities on the normal tissues caused by the use of doxorubicin. The root of Eurycoma longifolia Jack, a part of plant, has a potential activity as co-chemotherapy. This study aimed to determine the effect of cochemotherapy of ethyl acetate fraction of E. longifolia Jack roots and doxorubicin against cell proliferation activity by AgNOR method and determine expression of Bax protein of breast tissue in rats induced by DMBA. The rats were divided into five groups: I (baseline), II (DMBA 20 $\mathrm{mg} / \mathrm{kgBW}$ ), III (DMBA, doxorubicin $1.12 \mathrm{mg} / \mathrm{kg}$ ), IV (DMBA, fraction of $100 \mathrm{mg} / \mathrm{kg}$ ), and $V$ (DMBA, doxorubicin, fractions). All the rats were sacrificed at week 16. Their breast tissue was evacuated. Cell proliferation and expression was observed using AgNOR method and immunohistochemistry, respectively. Results showed the percentage of p-AgNOR obtained by the healthy group, DMBA group, DMBA+Doxorubicin group, DMBA+ethyl acetate fraction of E. longifolia Jack root group, and DMBA+Doxorubicin+Ethyl acetate fraction of E. longifolia group were $0 \pm 0 \%, 14.67 \pm 2.11 \%, 1.83 \pm 1.21 \%, 6.83 \pm 2.03 \%$, and $4.08 \pm 0.95 \%$, respectively. The percentage of Bax expression obtained by the healthy group, DMBA group, DMBA+Doxorubicin group, DMBA+ethyl acetate fraction of E. longifolia Jack root group, and DMBA+Doxorubicin+Ethyl acetate fraction of E. longifolia group were $68.82 \pm 1.52 \%$, $26.86 \pm 3.25 \%, 44.49 \pm 2.06 \%, 80.92 \pm 3.27 \%$, and $78.70 \pm 4.87 \%$, respectively. Based on the results, it was concluded that co-chemotherapy agent of ethyl acetate fraction of E. longifolia Jack roots and Doxorubicin could inhibit proliferation and trigger apoptosis through Bax expression in breast tissue of rats induced by DMBA.
\end{abstract}

Keywords: Eurycoma longifolia Jack root, Bax, co-chemotherapy, proliferation

\section{ABSTRAK}

Penggunaan agen ko-kemoterapi dibutuhkan sebagai akibat munculnya toksisitas pada jaringan normal yang disebabkan penggunaan doxorubicin. Akar pasak bumi (Eurycoma longifolia Jack) adalah tanaman yang memiliki potensi sebagai ko-kemoterapi. Penelitian ini bertujuan untuk mengetahui pengaruh pemberian ko-kemoterapi fraksi etil asetat akar pasak bumi dan Doxorubicin terhadap aktivitas proliferasi sel dengan metode AgNOR dan ekspresi protein Bax jaringan payudara pada tikus yang diinduksi DMBA. Tikus terbagi menjadi 5 kelompok : I (Baseline), II (DMBA $20 \mathrm{mg} / \mathrm{KgBB}$ ), III (DMBA, doxorubicin 1,12 mg/kg BB), IV (DMBA, 
fraksi100 mg/kg BB), dan V (DMBA, Doxorubicin, fraksi). Semua tikus dikorbankan pada minggu ke-16 dan diambil jaringan payudaranya. Pengamatan proliferasi menggunakan metode AgNOR dan ekspresi menggunakan imunohistokimia. Hasil persen p-AgNOR yang diperoleh kelompok sehat, DMBA, DMBA+Doxorubicin, DMBA+fraksi etil asetat akar pasak bumi, dan DMBA+Doxorubicin+Fraksi etil asetat akar pasak bumi sebesar 0 $\pm 0 \%, 14,67 \pm 2,11 \%, 1,83 \pm 1,21$ $\%, 6,83 \pm 2,03 \%$, dan 4,08 $\pm 0,95 \%$, berturut-turut. Persen ekspresi Bax diperoleh kelompok sehat, DMBA, DMBA+Doxorubicin, DMBA+fraksi etil asetat akar pasak bumi, dan DMBA+Doxorubicin+Fraksi etil asetat akar pasak bumi sebesar 68,82 $\pm 1,52 \%, 26,86 \pm 3,25 \%$,

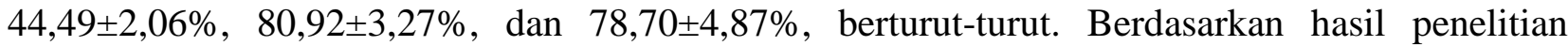
disimpulkan bahwa ko-kemoterapi fraksi etil asetat akar pasak bumi dan Doxorubicin dapat menghambat proliferasi dan memacu apoptosis melalui ekspresi Bax pada jaringan payudara tikus yang diinduksi DMBA.

Kata kunci: akar pasak bumi, Bax, ko-kemoterapi, proliferasi

\section{PENDAHULUAN}

Kanker menyebabkan terjadinya ketidakseimbangan antara proliferasi dan apoptosis. Sel-sel kanker tumbuh secara berlebihan terjadi akibat proses aktivitas proliferasi sel yang tidak terkendali. Perubahan pada sel kanker yang dihubungkan dengan biogenesis ribosom dapat ditunjukkan dengan kuantitas dari nuclear organization region (NOR) yang direaksikan dengan perak (Ag), yaitu AgNOR (Basher et al, 2016). Proliferasi sel yang tidak terkendali menyebabkan terganggunya gen atau protein pengatur pertumbuhan pada siklus sel sehingga dapat mengganggu regulasi apoptosis (Zhang and Liu, 2005). Perubahan pada gen pengatur apoptosis terutama diperankan oleh Bax dan Bcl-2. Peningkatan ekspresi Bcl-2 akan menghambat pengeluaran sitokrom c dari mitokondria sehingga Bax sebagai gen proapoptosis akan menurun dan menyebabkan penurunan kemampuan apoptosis sel sehingga dapat memicu proliferasi sel dan memunculkan kanker (Dlugosz et al, 2006).

Senyawa karsinogen yang banyak digunakan sebagai model dalam berbagai penelitian kanker adalah 7,2Dimetilbenz(a)antrasena (DMBA). Senyawa ini dapat menyebabkan kerusakan DNA yang ditandai dengan kesalahan pengkodean gengen pengatur pertumbuhan. Sitokrom P450 1B1 (CYP1B1) mengaktivasi DMBA untuk membentuk

DMBA-3,4-diol-1,2-epoksida yang bersifat karsinogenik (Rajapaksa et al, 2007).

Terapi yang digunakan pada kanker payudara yaitu dengan agen kemoterapi Doxorubicin. Penggunaan agen kemoterapi sangat toksik bagi jaringan normal (Wattanapitayakul et al., 2005). Untuk menurunkan toksisitas terhadap jaringan normal maka perlu dilakukan kombinasi dengan agen ko-kemoterapi (Sharma et al., 2004). Senyawa antikanker dan kokemoterapi sebagai alternatif pengobatan dapat diperoleh dari akar pasak bumi (Eurycoma longifolia Jack). Akar pasak bumi (Eurycoma longifolia Jack) mengandung kuasinoid (Bedir et.al.,2003), alkaloid 9metoksisantin-6-on (Nurhanan, et al., 2005), alkaloid canthinone (Chan et al, 2002), dan flavonoid (Nurani, 2011). Tsui Tee (2005) menyatakan bahwa ekstrak dan fraksi $E$. longifolia memiliki aktivitas antiproliferatif pada MCF-7 dengan menginduksi apoptosis melalui modulasi protein famili $\mathrm{Bcl}-2$. Kombinasi dari doxorubicin dengan fraksi etil asetat ekstrak etanol akar pasak bumi telah diketahui memiliki efek sinergis yang dapat menghambat proliferasi sel kanker T47D (Niah, 2015). Aktivitas proliferasi dapat dilihat dengan menggunakan metode AgNOR. Penelitian telah menunjukkan perbedaan yang signifikan dalam AgNOR skor untuk tumor payudara jinak dan ganas (Basher et al, 2016). Sel ganas mempunyai lebih banyak titik AgNOR per nukleus 
dibandingkan dengan lesi payudara jinak (Nepal and Talwar, 2014). Mekanisme molekuler fraksi etil asetat akar pasak bumi dan Doxorubicin juga memiliki aktivitas dalam menghambat proliferasi sel T47D melalui mekanisme peningkatan ekspresi Bax dan penurunan ekspresi Bcl-2 (Ahidin, 2015).

Penelitian ini dilakukan untuk melihat mekanisme ko-kemoterapi fraksi etil asetat akar pasak bumi dan Doxorubicin dengan melihat aktivitas proliferasi sel dan apoptosis. Parameter yang dilihat adalah dengan menghitung NOR dan ekspresi protein Bax pada jaringan payudara tikus.

\section{METODE PENELITIAN \\ Bahan dan alat}

Bahan yang akan digunakan adalah akar pasak bumi, CMC Na 0,5\%, corn oil (Superindo 365), 7,12 dimetilbenz(a)antrasen (DMBA) $20 \mathrm{mg} / \mathrm{KgBB}$ (SIGMA Aldrich), doxorubicin murni (OGB Sanbe $2 \mathrm{mg} / \mathrm{ml}$ ), etanol $70 \%$ (Genera Labora), formaldehid $10 \%, \mathrm{NaCl}$ fisiologis. Hewan uji yang akan digunakan pada penelitian ini adalah tikus betina galur SD (Sprague Dawley) dengan berat badan 100- $200 \mathrm{~g}$ dan berumur 2 bulan (Kubatka et al., 2002).

Alat-alat yang digunakan adalah magnetic stirer (LABINCO), toples, timbangan analitik (HWH), rotary evaporator (Heidolph), seperangkat alat bedah, oven (BindeR), chamber (Larrag), waterbath (Memmert), alat-alat gelas (Pyrex), optilab yang dihubungkan dengan komputer (OLYMPUS DP12).

\section{Jalan Penelitian \\ Pengumpulan Bahan}

Akar pasak bumi diperoleh dari Martapura, Kalimantan Selatan kemudian dikeringkan dengan menggunakan oven dan diserbuk dengan blender di Laboratorium Teknologi Sediaan Farmasi UAD.

\section{Ekstraksi dan Fraksinasi akar pasak bumi}

Serbuk akar pasak bumi dimaserasi dengan etanol $70 \%$ menggunakan pengaduk elektrik, pengadukan dilakukan selama 3 jam, kemudian didiamkan selama 24 jam. Setelah itu disaring hingga diperoleh filtrat dan rendemen. Filtrat yang ada dikumpulkan dan dipekatkan menggunakan rotary evaporator pada suhu $50-60^{\circ} \mathrm{C}$ kemudian dipekatkan lebih lanjut di atas waterbath pada suhu $70^{\circ} \mathrm{C}$ sampai diperoleh ekstrak kental (Nurani, 2011).

Sebanyak $50 \mathrm{~g}$ ekstrak etanol difraksi menggunakan $20 \mathrm{~mL}$ etil asetat dan dilakukan dengan cara enap tuang sebanyak 5 kali. Partisi dilakukan sampai senyawa yang harus masuk ke dalam etil asetat tersari semua yang ditunjukkan oleh hasil KLT yang terlihat terpisah antara fase larut etil asetat dan tak larut etil asetat. Fase atau bagian tersebut kemudian dipekatkan sehingga diperoleh fraksi larut etil asetat dan tak larut etil asetat (Nurani, 2011).

\section{Pembuatan Larutan karsinogen 7,12- Dimetilbenz(a)antrasen (DMBA)}

Larutan karsinogen DMBA dibuat dengan pelarut minyak jagung (Corn Oil). Larutan DMBA kemudian diberikan peroral pada hewan uji dengan dosis $20 \mathrm{mg} / \mathrm{kgBB}$ selama 5 minggu dengan pemberian 2 kali seminggu. Larutan DMBA selalu dibuat baru, sebelum diberikan kepada hewan uji (Meiyanto et al., 2007).

\section{Pembuatan Sampel Uji}

Fraksi etil asetat ekstrak etanol akar pasak bumi dilarutkan dalam CMC-Na 0,5\%. Pembuatan CMC-Na dilakukan dengan pemanasan campuran CMC-Na dan akuades hingga $100^{\circ} \mathrm{C}$ yang disertai pengadukan menggunakan magnetic stirrer (Nurani, 2011).

\section{Pengelompokkan Hewan Uji}

Hewan diadaptasikan dalam kandang selama satu minggu sebelum perlakuan dan dipelihara di kandang tikus Laboratorium Farmasi Universitas Ahmad Dahlan Yogyakarta. Hewan uji telah mendapatkan surat persetujuan etik (Etichal Approval) dari Komite Etik Penelitian Universitas Ahmad Dahlan (KEP UAD) dengan nomor 01150504. 
Tikus betina galur Sprague Dawley umur 2 bulan sebanyak 35 ekor, dibagi menjadi lima kelompok secara random. Masing-masing kelompok terdiri dari tujuh ekor tikus, yaitu Kelompok 1 tikus sehat hanya diberi pakan, Kelompok 2 (kontrol negatif) diberikan DMBA $20 \mathrm{mg} / \mathrm{KgBB}$ secara oral 2 kali seminggu, diberikan selama 5 minggu dimulai sejak minggu ke-1, Kelompok 3 diberi DMBA+Doxorubicin 1,12 $\mathrm{mg} / \mathrm{kg} \mathrm{BB}$, pemberian Doxorubicin selama 5 minggu (1 minggu sekali), Kelompok 4 diberi DMBA+FEA akar pasak bumi, dan Kelompok 5 diberi DMBA + Doxorubicin + FEA akar pasak bumi.

\section{Pemeriksaan Aktivitas Proliferasi Dengan Metode AgNOR}

Irisan jaringan dari organ payudara tikus yang diperoleh dari proses jaringan direndam dalam buffer sodium sitrat $(\mathrm{pH} 6,0)$ kemudian diinkubasi di dalam autoclave pada suhu $120^{\circ} \mathrm{C}$ selama 20 menit. Setelah didinginkan sampai suhu $37^{\circ} \mathrm{C}$, slide kemudian direndam dalam larutan pengecatan perak yang terdiri dari 1 bagian volume gelatin $0,5 \%$ dalam asam formiat $1 \%$ dan 2 bagian larutan perak nitrat $50 \%$ dan diinkubasi pada suhu $37^{\circ} \mathrm{C}$, selama 11 menit. Reaksi dihentikan dengan mencuci slide menggunakan aqua bidestilata untuk menghilangkan presipitat perak non-spesifik. Selanjutnya, semua jaringan didehidrasi menggunakan etanol dengan konsentrasi yang dinaikkan secara bertingkat, dibersihkan dengan xylene dan ditempelkan bersama medium sintetis (Bankfalvi et al, 2002). Pembuatan preparat AgNOR dilakukan di Laboratorium Patologi Anatomi Fakultas Kedokteran UGM.

\section{Imunohistokimia}

Penelitian ini menggunakan mouse monoclonal antibody Bax produksi Santa Cruz. Prosedur yang digunakan untuk imunohistokimia dalam penelitian ini dilakukan sesuai dengan prosedur standar dari Laboratorium Patologi Anatomi, RSUP Dr. Sardjito Yogyakarta (Chang, 2009).

\section{Analisis Data}

Analisis data untuk parameter proliferasi dilihat dari jumlah AgNOR tiap sel yang dihitung di bawah mikroskop. Penghitungan AgNOR dalam penelitian ini menggunakan $\mathrm{p}$ AgNOR yang merupakan persentasi jumlah sel dengan titik hitam di atas lima terhadap keseluruhan sel yang diamati, pada minimal sel tiap pengamatan 100 sel. Perhitungan ekspresi Bax dihitung sel yang positif berwarna coklat dalam persen dengan cara sebagai berikut.

$$
\% \text { Ekspresi Protein Bax }=\frac{S_{B}}{S_{T}} \times 100 \%
$$

\section{Keterangan:}

$\mathrm{S}_{\mathrm{B}}$ : jumlah sel yang mengekspresikan protein Bax $\mathrm{S}_{\mathrm{T}}$ : Jumlah sel keseluruhan

Data yang diperoleh yaitu persen AgNor dan persen ekspresi protein Bax yang diuji distribusi normalnya dengan KolmogorovSmirnov dan homogenitasnya dengan uji Levene kemudian dilanjutkan dengan uji ANOVA atau Kruskal Wallis (taraf kepercayaan $95 \%$ ). Data diuji secara statistik menggunakan SPSS 16.0 for windows (Yuliarto, 2013).

\section{HASIL DAN PEMBAHASAN}

\section{Identifikasi Tanaman Akar Pasak Bumi}

Identifikasi akar pasak bumi dilakukan di Laboratorium Biologi Universitas Ahmad Dahlan dengan nomor 014/Lab.Bio/B/I/2016. Adapun hasil identifikasi adalah sebagai berikut : Familia: Simarubaceae, Genus: Eurycoma, dan Jenis: Eurycoma longifolia Jack. Berdasarkan hasil identifikasi, maka dapat ditarik kesimpulan bahwa tanaman uji yang digunakan dalam penelitian ini adalah akar pasak bumi (Eurycoma longifolia Jack).Akar pasak bumi selanjutnya diserbuk hingga didapatkan serbuk halus untuk dibuat menjadi ekstrak.

\section{Pembuatan Fraksi Etil Asetat Ekstrak Etanol Akar Pasak Bumi}

Ekstrak etanol akar pasak bumi diperoleh sebanyak 121,36 g dengan ciri organoleptis berwarna coklat gelap, berasa pahit, kental dan tercium bau khas. Rendemen ekstrak etanol akar pasak bumi adalah sebesar 
2,92\%. Selanjutnya dilakukan fraksinasi dengan penambahan pelarut etil asetat yang lebih non polar dibandingkan dengan etanol untuk memperkecil komponen senyawa yang tertarik ke pelarut etil asetat.

Ekstrak etanol akar pasak bumi difraksinasi dengan perbandingan 1:2,5 (etil asetat : ekstrak).

Pemilihan fraksi etil asetat sebagai pelarut berdasarkan pada penelitian-penelitian sebelumnya yang menyatakan bahwa pada sel T47D fraksi etil asetat ekstrak etanol akar pasak bumi mempunyai aktivitas sitotoksik yang lebih besar daripada fraksi tidak larut etil asetat (Nurani, 2011). Setelah difraksinasi, sampel dilakukan uji kualitatif dengan metode kromatografi lapis tipis. Bercak pada ekstrak etnaol dan fraksi etil asetat memiliki nilai $\mathrm{Rf}$ yang sama pada bercak pertama yaitu 0,55. Hal ini menunjukkan bahwa fraksi etil asetat akar pasak bumi mengandung senyawa eurycomanone secara KLT dimana pada penelitian Arifah (2014) menunjukkan bahwa nilai $\mathrm{Rf}$ standar eurycomanone sama dengan ekstrak etanol dan fraksi etil asetat yaitu 0,55.

\section{Uji Antiproliferasi dengan Pengecatan AgNOR}

Nuclear organizer region (NOR) adalah loop DNA pada tangan pendek 5 kromosom akrosentrik $(13,14,15,21$, dan 22) dari nukleoli sel-sel dan berhubungan dengan aktivitas gen ribosomal RNA sintesis protein dan proliferasi sel (Rizali and Auerkari, 2003). Jumlah AgNOR tiap inti berhubungan dengan aktivitas pembelahan sel yang terjadi pada fase interfase (Bankfalvi et al., 2002). Jumlah NOR satu dianalogkan sebagai jumlah NOR yang merupakan sel normal. Pertambahan jumlah NOR menunjukkan proliferasi sel semakin meningkat sehingga tingkat keparahan kanker semakin meningkat (Ibnerasa et al., 2005). Gambaran sel dengan pengecatan AgNOR pada jaringan payudara tikus setelah diberi ko-kemoterapi fraksi etil asetat akar pasak bumi ditunjukkan pada Gambar 1.
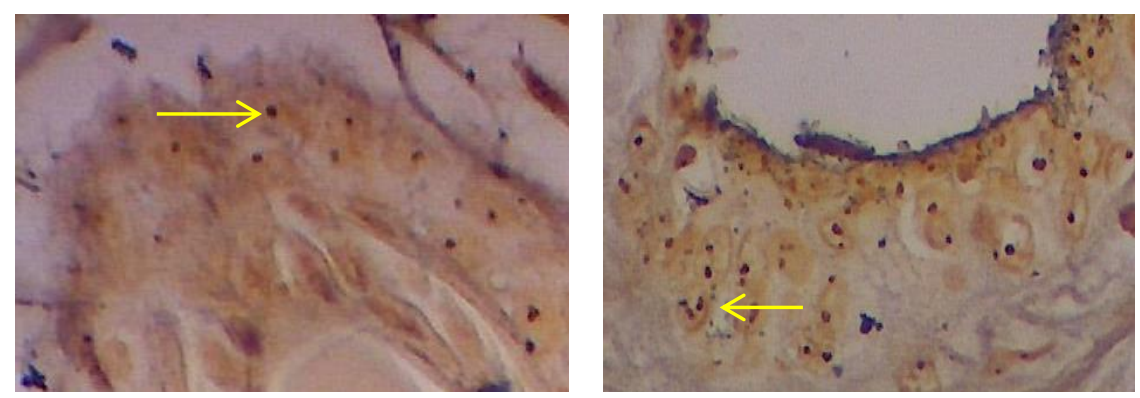

Gambar 1. Foto mikroskopik hasil perbesaran 400x pengecatan AgNOR (1) kelompok normal (2) kelompok DMBA. Keterangan $: \longrightarrow$ : Titik AgNOR
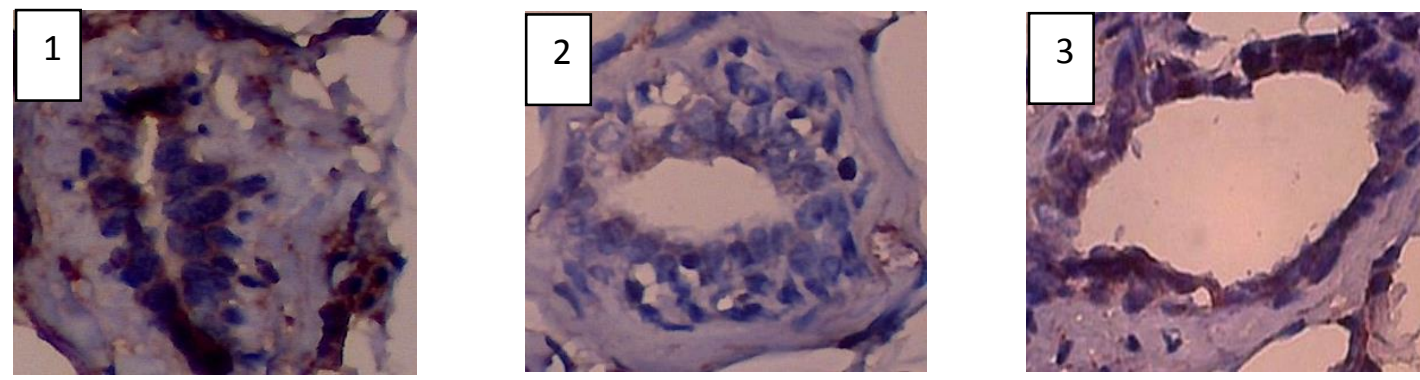

Gambar 2. Foto mikroskopis hasil perbesaran 400x uji imunohistokimia Bax (1) Kontrol normal (2) Kelompok DMBA 20 mg/kg BB (3) DMBA 20 mg/kg BB + Doxorubicin 1,12 mg/kg BB + APB 100 mg/kg BB 
Pada sel normal (kelompok normal) yang terlihat pada Gambar 1 tidak tampak aktivitas proliferasi sel yang tinggi. Hal ini ditunjukkan dengan tidak adanya sel yang memiliki titik AgNOR lebih dari lima per nukleus. Sedangkan pada kelompok yang diberikan DMBA $20 \mathrm{mg} / \mathrm{kg}$ BB lebih banyak sel yang memiliki titik AgNOR lebih dari lima sehingga menunjukkan adanya aktivitas proliferasi yang meningkat. Hasil pengamatan menggunakan mikroskop 400x yang dilengkapi optilab kemudian dilakukan perhitungan persentasae $\mathrm{p}$ AgNOR dengan cara jumlah sel yang memiliki titik AgNOR lebih dari lima dibagi 100 sel. Hasil pengamatan jumlah rata-rata sel yang memiliki lebih dari lima AgNOR seperti pada Tabel I.

Hasil penelitian menunjukkan adanya perbedaan yang bermakna antara kelompok normal dan kelompok DMBA yang terlihat pada Tabel I. Persentase jumlah p-AgNOR kelompok DMBA dibandingkan dengan kelompok sehat adalah $14,67 \pm 2,11$ dan $0 \pm$ 0 . Sel ganas mempunyai lebih banyak titik AgNOR per nukleus dibandingkan dengan lesi payudara jinak (Nepal and Talwar, 2014). Hal ini dapat terjadi karena disebabkan oleh metabolit aktif dari DMBA yaitu 3,4-dihidrodiol-1,2-epoksida yang dapat menyebabkan kerusakan DNA. Zat karsinogenik DMBA mengakibatkan peningkatan tumorigenesis karena peningkatan frekuensi mutasi pada gen penekan tumor dan penurunan perbaikan DNA sehingga menyebabkan pertumbuhan yang tidak terkontrol dari sel-sel dan menyebabkan terbentuknya kanker (Hollander et al., 2001).
Agen kemoterapi yang digunakan sebagai first line dalam pengobatan kanker payudara adalah Doxorubicin (Smith et al., 2006). Hasil menunjukkan pada kelompok yang diberikan DMBA $20 \mathrm{mg} / \mathrm{kg} \mathrm{BB}+$ Doxorubicin $1,12 \mathrm{mg} / \mathrm{kg}$ BB memiliki nilai p-AgNOR yang menurun dibandingkan dengan kelompok yang diberikan DMBA 20 $\mathrm{mg} / \mathrm{kg}$ BB. Persentase $\mathrm{p}$-AgNOR dari kedua kelompok adalah 1,83 $\pm 1,21$ dan 14,67 \pm 2,11. Doxorubicin bekerja melalui penghambatan topoisomerase II, interkalasi DNA sehingga mengakibatkan penghambatan sintesis DNA dan RNA pada sel kanker, pengikatan membran sel yang menyebabkan aliran dan transport ion sehingga dapat menghambat terjadinya pertumbuhan atau proliferasi dari sel kanker (Brunton, 2005). Penggunaan Doxorubicin tidak hanya menyebabkan toksisitas pada sel kanker namun juga pada sel normal. Hal ini disebabkan oleh mekanisme toksisitas dari Doxorubicin. Toksisitas kronis doxorubicin kemungkinan diperantarai oleh konversi metabolik doxorubicin menjadi doxorubicinol yang melibatkan berbagai enzim antara lain karbonil reduktase. Mekanisme utama toksisitas doxorubicinol terjadi karena interaksinya dengan besi dan pembentukan reactive oxygen species (ROS) yang merusak makromolekul sel (Minotti et al., 2004). Untuk meminimalkan efek samping penggunaannya maka Doxorubicin dikombinasikan dengan agen ko-kemoterapi yaitu fraksi etil asetat akar pasak bumi yang memiliki kandungan senyawa yang berefek sebagai antikanker.

Tabel I. Persentase Jumlah Rata-Rata Sel yang Memiliki Lebih dari Lima Titik AgNOR

\begin{tabular}{cc}
\hline Kelompok & Persentase Jumlah Rata-Rata sel \pm SD \\
\hline Normal & $0 \pm 0$ \\
DMBA & $14,67 \pm 2,11$ \\
DMBA+Doxo & $1,83 \pm 1,21$ \\
DMBA+APB & $6,83 \pm 2,03$ \\
DMBA+Doxo+APB & $4,08 \pm 0,95$ \\
\hline
\end{tabular}


Tabel II. Hasil Pengamatan Rata-Rata Persentase Ekspresi Protein Bax Setelah Diberikan Perlakuan Ko-Kemoterapi

\begin{tabular}{cc}
\hline Kelompok & Rata-Rata Persen Ekspresi Bax $(\%) \pm$ SD \\
\hline Normal & $68,82 \pm 1,52$ \\
DMBA & $26,86 \pm 3,25$ \\
DMBA+Doxo & $44,49 \pm 2,06$ \\
DMBA+APB & $80,92 \pm 3,27$ \\
DMBA+Doxo+APB & $78,70 \pm 4,87$ \\
\hline
\end{tabular}

Aktivitas zat aktif kuasinoid ekstrak akar pasak bumi sebagai antikanker melalui mekanisme pemacuan apoptosis atau penghambatan proliferasi sel (Tee and Hwariah, 2007). Adanya penghambatan proliferasi dapat dilihat dari persentase $\mathrm{p}$ AgNOR kelompok DMBA $20 \mathrm{mg} / \mathrm{kg} \mathrm{BB}+$ fraksi etil asetat akar pasak bumi $100 \mathrm{mg} / \mathrm{kg}$ BB yang mengalami penurunan dibandingkan kelompok DMBA $20 \mathrm{mg} / \mathrm{kg}$ BB yaitu $6,83 \pm 2,03$ dan $14,67 \pm 2,11$. Tee (2005) menyatakan bahwa ekstrak dan fraksi akar pasak bumi (EurycomalongifoliaJack) memiliki aktivitas antiproliferatif pada MCF-7. Adanya penurunan persentase $p$ AgNOR juga terjadi pada kelompok kokemoterapi yaitu kelompok DMBA 20 $\mathrm{mg} / \mathrm{kg} \mathrm{BB}+$ Doxorubicin 1,12 mg/kg BB + Fraksi etil asetat akar pasak bumi $100 \mathrm{mg} / \mathrm{kg}$ BB dengan persentase p-AgNOR sebesar $4,08 \pm 0,95$. Kemungkinan senyawa aktif aktif 14, 15 $\beta$ dihidroksilaineanon dan eurycumanone diantara golongan kuasinoid dari akar pasak bumi (Eurycoma longifolia Jack) yang dapat menghambat sel kanker, seperti sel kanker T47D (Kuo et al., 2003). Penghambatan pertumbuhan sel kanker T47D bisa terjadi melalui cell cycle delay, dimana daur sel akan tetap berjalan namun diperlambat atau ditunda (Shapiro et al., 1999). Cell Cycle delay berlangsung pada fase G1 dan memasuki keadaan diam fase G0 (Alberts et al., 1994). Aktivitas zat aktif kuasinoid akar pasak bumi sebagai antikanker juga diduga melalui mekanisme pemacuan apoptosis atau penghambatan proliferasi sel kanker dengan melibatkan kerja enzim antioksidan dan respon imun seluler (Tee and Hwariah, 2006).

Selain mengandung kuasinoid, akar pasak bumi juga mengandung flavonoid (Nurani, 2011). Senyawa flavonoid yang ditemukan dalam akar pasak bumi adalah 3,5,6,7,8,3,4-heptamethoxyflavone. Senyawa flavonoid dapat menghambat proliferasi melalui inhibisi prosesoksidatif yang dapat menyebabkan inisiasi kanker. Mekanisme ini diperantarai penurunan enzim xanthin oksidase, siklooksigenase (COX) dan lipooksigenase (LOX) yang diperlukan dalam proses prooksidasi sehingga menunda siklus sel (Ren et al., 2003). Doxorubicin bekerja melalui mekanisme interkalasi DNA sehingga mengakibatkan penghambatan sintesis DNA dan RNA, pengikatan membran sel juga melalui pembentukan radikal bebas semiquinon dan radikal bebas oksigen (Brunton, 2005). Terjadinya penurunan $\mathrm{p}-\mathrm{AgNOR}$ menunjukkan bahwa ko-kemoterapi Doxorubicin 1,12 mg/kg BB dan fraksi etil asetat akar pasak bumi 100 $\mathrm{mg} / \mathrm{kg}$ BB dapat menghambat proliferasi sel. Oleh karena itu, penelitian dilanjutkan dengan imunohistokimia terhadap ekspresi protein Bax untuk melihat terjadinya apoptosis dari sel kanker.

\section{Imunohistokimia Bax}

Ko-kemoterapi fraksi etil asetat akar pasak bumi dan Doxorubicin perlu ditelusuri lebih lanjut aktivitasnya dengan mengamati ekspresi protein Bax. Protein Bax merupakan 
suatu anggota famili protein Bcl-2 yang dapat meningkatkan apoptosis (Khan et al ., 2007). Protein Bax yang terekspresi akan berwarna ungu coklat lebih intensif dan terekspresi pada inti sel dan sitoplasma (Shen et al, 2006). Ekspresi protein Bax diamati setelah 16 minggu pemberian perlakuan mengunakan mikroskop dengan perbesaran 400x yang dilengkapi optilab. Gambaran sel yang mengekspresikan protein Bax pada jaringan payudara tikus setelah diberi kokemoterapi fraksi etil asetat akar pasak bumi dan Doxorubicin kemudian dicat dengan antibodi Bax terlihat pada Gambar 2.

Berdasarkan Gambar 2 dapat dilihat bahwa kelompok DMBA jika dibandingkan dengan kelompok normal menunjukkan adanya perbedaan warna yaitu warna coklat yang terbentuk hanya sedikit. Warna coklat tersebut adalah protein Bax yang terekspresi. Hal ini menunjukkan bahwa hewan uji yang diinduksi DMBA mengekspresikan protein Bax dalam jumlah sedikit karena metabolit reaktifdari DMBA akan menyebabkan kerusakan DNA (Meiyanto et al, 2007). Kerusakan DNA dapat menyebabkan mutasi gen P53 sehingga ekspresi Bcl-2 akan meningkat yang akan menghambat gen proapoptosis yaitu Bax sehingga dapat dilihat pula jumlah sel lebih banyak dan terlihat lebih padat karena apoptosis terhambat dan proliferasi sel tetap terus berjalan. Pada kelompok yang diberikan kokemoterapi fraksi etil asetat akar pasak bumi dan Doxorubicin juga memperlihatkan terbentuknya warna coklat yang lebih banyak dan intensif dibandingkan dengan kelompok DMBA $20 \mathrm{mg} / \mathrm{kg}$ BB. Hal tersebut menunjukkan bahwa pemberian kokemoterapi fraksi etil asetat akar pasak bumi dan Doxorubicin mampu menyebabkan apoptosis, sehingga proliferasi sel dapat terhambat (Shapiro et al., 1999).

Setelah pengamatan menggunakan mikroskop 400x yang dilengkapi optilab kemudian dilakukan perhitungan persentase ekpresi protein Bax. Analisis persentase ekspresi Bax dihitung dengan cara menghitung jumlah sel yang terekspresi dibagi jumlah sel keseluruhan dikali dengan
$100 \%$. Hasil pengamatan persentase ekspresi protein Bax setelah diberikan perlakuan dapat dilihat pada Tabel II.

Hasil penelitian menunjukkan persen ekspresi Bax pada kelompok DMBA 20 $\mathrm{mg} / \mathrm{kg} \quad \mathrm{BB}$ lebih sedikit dibandingkan kelompok normal. Kelompok DMBA 20 $\mathrm{mg} / \mathrm{kg}$ BB memliki persen ekspresi Bax sebesar 26,86 $\pm 3,25$, sedangkan kelompok normal sebesar 68,82 $\pm 1,52$. Hal ini disebabkan karena DMBA mengakibatkan kerusakan DNA dapat menyebabkan mutasi gen P53 sehingga ekspresi Bcl-2 akan meningkat yang akan menghambat gen proapoptosis yaitu Bax sehingga dapat dilihat jumlah protein Bax menurun. Keadaan ini selanjutnya akan mengakibatkan sel tidak mengalami apoptosis dan terus berproliferasi.

Doxorubicin banyak digunakan dalam terapi kanker payudara .Doxorubicin mengaktivasi nitrogen yang diaktivasi protein kinase (MAPKs), p38 dan JNK, dan meningkatkan apoptosis dengan mengurangi level dari ekspresi protein anti apoptosis seperti Bcl-2 dan meningkatkan level ekspresi dari protein pro apoptosis seperti Bax (Shi et al, 2011; Zhivotovsky et al., 2006). Dapat dilihat dari persentase ekspresi Bax pada kelompok DMBA $20 \mathrm{mg} / \mathrm{kg}$ $\mathrm{BB}+$ Doxorubicin $1,12 \mathrm{mg} / \mathrm{kg} \quad \mathrm{BB}$ yang mengalami peningkatan sebesar 44,49 $\pm 2,06$ dibandingkan kelompok DMBA $20 \mathrm{mg} / \mathrm{kg}$ BB yaitu 26,86 $\pm 3,25$. Hal ini membuktikan bahwa Doxorubicin dapat meningkatkan ekspresi Bax yang selanjutnya akan memicu terjadinya apoptosis. Selanjutnya melihat aksi ko-kemoterapi fraksi etil asetat akar pasak bumi dan Doxorubicin yang bertujuan untuk mengurangi efek samping yang dimunculkan oleh Doxorubicin dan meningkatkan sensitifitas sel kanker.

Tee (2005) menyatakan bahwa ekstrak dan fraksi E. longifolia memiliki aktivitas antiproliferatif pada MCF-7 dengan menginduksi apoptosis melalui modulasi protein Bcl-2. Bcl-2 dan Bax adalah anggota dari keluarga protein Bcl-2 yang dikaitkan dengan kematian sel melalui apoptosis. Hal ini terlihat pada kelompok DMBA $20 \mathrm{mg} / \mathrm{kg}$ 
$\mathrm{BB}+$ Fraksi etil asetat akar pasak bumi 100 $\mathrm{mg} / \mathrm{kg}$ BB yang mengalami peningkatan dibandingkan dengan kelompok DMBA 20 $\mathrm{mg} / \mathrm{kg} \mathrm{BB}$, hasil analisis statistik pun menunjukkan bahwa kedua kelompok terdapat perbedaan bermakna dengan siginifikansi $0,000 \quad(\mathrm{p}<0,05)$. Persentase ekspresi protein Bax pada kelompok DMBA $20 \mathrm{mg} / \mathrm{kg} \mathrm{BB}+$ Fraksi etil asetat akar pasak bumi $100 \mathrm{mg} / \mathrm{kg}$ BB merupakan persentase tertinggi dibandingkan kelompok lainnya yaitu sebesar 80,92 $\pm 3,27$.

Hasil penelitian juga menunjukkan adanya perbedaan bermakna dari kelompok ko-kemoterapi Fraksi etil asetat akar pasak bumi $100 \mathrm{mg} / \mathrm{kg} \quad \mathrm{BB}+$ Doxorubicin 1,12 $\mathrm{mg} / \mathrm{kg} \quad \mathrm{BB}$ dengan nilai signifikansi dibandingkan dengan kelompok DMBA 20 $\mathrm{mg} / \mathrm{kg}$ BB adalah 0,000 $(\mathrm{p}<0,05)$. Persentase ekspresi protein dari pemberian kokemoterapi ini terjadi peningkatan dibanding kelompok DMBA $20 \mathrm{mg} / \mathrm{kg}$ BB yaitu sebesar 78,70 $\pm 4,87$. Hal ini karena adanya efek sinergis dari Doxorubicin dan fraksi etil asetat. Pemacuan apoptosis fraksi etil asetat akar pasak bumi terjadi melalui peningkatan persentase ekspresi tumor supresor gen p53 dan penurunan persentase ekspresi protein Bcl-2 sehingga akan meningkatkan persentase dari Bax yang merupakan protein pro-apoptosis disebabkan oleh kuasinoid, alkaloid, dan flavonoid yang terkandung didalamnya (Kardono et al., 1991; Itokawa et al., 1993; Kuo et al., 2003; Guo et al., 2005). Kuasinoid fraksi etil asetat akar pasak bumi yang diduga terlibat dalam mekanisme ini adalah eurycumanone (Mahfudh and Pihie, 2008). Aktivitas antikanker juga ditunjukkan flavonoid melalui induksi apoptosis.Flavonoid menghambat ekspresi enzim topoisomerase I dan topoisomerase II yang berperan dalam katalisis pemutaran dan relaksasi DNA.Inhibitor enzim terpotongdan mengalami kerusakan. Kerusakan DNA dapat menyebabkan terekspresinyaprotein proapoptosis seperti Bax dan Bak dan menurunkan ekspresi protein-protein antiapoptosis yaitu Bcl-2 dan Bcl-XL. Dengan demikian pertumbuhan sel kanker terhambat. Sebagian besar flavonoid telah terbukti mampu menghambat proliferasi pada berbagai sel kanker pada manusia namun bersifat tidak toksik pada sel normal manusia (Ren et al., 2003).

Doxorubicin mengaktivasi nitrogen yang diaktivasi protein kinase (MAPKs), p38 dan JNK, dan meningkatkan apoptosis kardiomiosit dengan mengurangi level dari ekspresi protein anti apoptosis seperti $\mathrm{Bcl}-2$ dan meningkatkan level ekspresi dari protein pro apoptosis seperti Bax 3 (Shi et al, 2011 ; Zhivotovsky et al., 2006). Adanya pengurangan ekspresi protein dari Bcl-2 dan peningkatan ekspresi dari protein Bax, selanjutnya protein Bax akan mendorong pelepasan sitokrom c pada mitokondria, yang akhirnya akan membentuk suatu komplek dengan Apoptosis Inducing Factor-1 (APAF1), prokaspase-9 dan Adenosine-Triphospat (ATP). Komplek tersebut mengakibatkan terjadinya aktivasi prokaspase-9 menjadi kaspase-9, kemudian kaspase-9 akan memicu aktivasi dari kaspase-3. Kaspase-3 merupakan kaspase terakhir atau eksekutor yang memecah DNA dan substrat lainnya sehingga mengakibatkan terjadinya kematian sel (Kumar et al, 2010).

Dari hasil penelitian yang diperoleh menunjukkan bahwa ko-kemoterapi fraksi etil asetat akar pasak bumi dan Doxorubicin efektif sebagai antikanker, dilihat dari penghambatan proliferasi yang ditunjukkan dengan menurunnya persentase $\mathrm{p}$-AgNOR dan hasil ekspresi protein Bax yang semakin meningkat dengan adanya ko-kemoterapi dibandingkan dengan yang tidak diberikan sampel. Hasil diatas sesuai dengan penelitian yang dilakukan secara in vitro oleh Ahidin (2015) bahwa fraksi etil asetat akar pasak bumi dan Doxorubicin memiliki aktivitas dalam menghambat sel T47D melalui mekanisme peningkatan ekspresi Bax dan penurunan ekspresi Bcl-2. Dengan adanya ko-kemoterapi fraksi etil asetat dan Doxorubicin dapat menghambat pertumbuhan sel kanker melalui cell cycle delay dan melalui peningkatan ekspresi Bax sebagai protein proapoptosis sehingga menyebabkan pelepasan sitokrom $\mathrm{C}$ dari mitokondria ke sitosol yang akan 
mengaktifkan kaspase 9 dan kaspase 3, dimana kaspase 3 merupakan kaspase terakhir yang memecah DNA dan substrat lainnya sehingga mengakibatkan terjadinya kematian sel.

\section{KESIMPULAN}

Ko-kemoterapi fraksi etil asetat akar pasak bumi dan Doxorubicin dapat menghambat proliferasi sel kanker dengan menurunnya persentase jumlah NOR pada nukleolus dan dapat memacu apoptosis dengan peningkatan ekspresi protein Bax.

\section{UCAPAN TERIMA KASIH}

Ucapan terima kasih kepada DIKTI melalui pendanaan program hibah tim pascasarjana TA 2015/2016 dan LPP UAD atas biaya yang diberikan dalam penelitian ini.

\section{DAFTAR PUSTAKA}

Ahidin, D., 2015. Efek Ko-Kemoterapi Fraksi Etil Asetat Ekstrak Etanol Akar Pasak Bumi (Eurycoma longifolia Jack) Dan Doxorubicin Terhadap Ekspresi Bax Dan Bcl-2 Pada Sel T47D. Tesis, Ahmad Dahlan, Yogyakarta.

Alberts, B., Bray, D., Lewis, J., Raff, M., Roberts, K., Watson, J. D., 1994. Molecular Biology of the Cell, 3rd edition. Garland Publishing, New York.

Antonsson, B., Martinou, J.C., 2000. The Bcl-2 Protein Family, Exp. Cell. Res, 256, 50-57

Arifah, A.N., Nurkhasanah, 2014. Efek Fraksi Etil Asetat Ekstrak Etanol Akar Pasak Bumi (Eurycoma longifolia, Jack) terhadap Aktivitas Fagositosisi Makrofag secara In Vitro. Pharmaçiana, 4(1), 9-14.

Bankfalvi A, Giuffre G, Ofner D, Diallo R, Poremba C, Buchwlow IB, 2002. Relationship Between HER-2 Status and Proliferation Rate in Braest Cancer Assessed by Imunohistochemisty, Fluorecence In situ Hibriditation and Standardised AgNOR Analysis.
International Journal of Oncology, 23, 1285-92.

Basher, E. S., Hassan, A. M., Awad, M. H., 2016. Micronuclei and Ag NOR as biomarker in fine needle aspiration cytology of breast tumor. American Journal of Research Communication, 4(1).

Bedir,E., Abou-Gazar, H., Ngwendson, J.N., Khan I.A., 2003. Eurycomanoside: A New Quassinoid From The Roots Of Eurycoma longifolia Jack. Chem. Pharm. Bull, 51(11), 1301-1303.

Blundell R.A., 2006. The Biology of p21Waf1/Cip1-Review Paper. Am.J. Biochem and Biotechnol, 2 (1), 33-40.

Brunton, L. L., 2005. Gilman's The Pharmacological Basic Of Therapeutics (Vol. 11th), Mc GrawHill, New York

Chan, K., L., Choo, C., Y., Abdullah, N., R., Ismail, Z., 2002. Semisynthetic 15-Oacyl- and 1,15-di-Oacyleurycomanones from Eurycoma longifolia as potential antimalarials. Plan Med, 71 (10), 967-9.

Chang, B., Liu, G., Xue, F., Rosen, D. G., Xiao, L., Wang, X., et al., 2009. ALDH1 expression correlates with favorable prognosis in ovarian cancers. Modern Pathology, 22(6), 817-823.

Dlugosz, P. J., Billen, L. P., Annis, M. G., Zhu, W., Zhang, Z., Lin, J., et al, 2006. Bcl-2 changes conformation to inhibit Bax oligomerization. The EMBO journal, 25(11), 2287-2296.

Ellis EO, Schnitt SJ, Sastre-Garau X, 2003. Invasive Breast Carcinoma. In: Pathology and Genetics of Tumors of The Breast Cancer and Female Genital Organ. IARC Press.

Gottlieb, T.M., Oren, M., 1998. P53 and Apoptosis. Cancer Biol, 8 (1998), 359-368.

Guo, Z., Vangapandu, S., Sindelar, R.W., Walker, L.A., and Sindelar, R.D., 2005. Biological active quassinoids and their chemistry: potential leads for 
drug design, Curr Med Chem, 12, 173190.

Hollander, M. C., Kovalsky, O., Salvador, J. M., Kim, K. E., Patterson, A. D., Haines, D. C., et al., 2001. Dimethylbenzanthracene carcinogenesis in Gadd45a-null mice is associated with decreased DNA repair and increased mutation frequency. Cancer research, 61(6), 2487-2491.

Ibnerasa, S. N., Chaudhry, N. A., Khan, S. A., 2005. AgNOR Proliferative Index in Malignant Pleural and Peritoneal Effusions. International Journal of Pathology, 3(2), 86-90.

Itokawa, H., Kishi, E., Morita, H., Takeya, K., 1993. Cytotoxic quassinoids and tirucallane-tyspe triterpenes from the woods of Eurycoma longifolia. Chem. Pharm. Bull., 40, 1053-1055.

Kardono L.B.S., Angerhofer C.K., Tsauri S, Padmawinata K, Pezzuto J.M., Kinghorn A.D., 1991. Cytotoxic and antimalarialconstituents of the roots of Eurycomalongifolia. J. Nat Prod, 54, 1360-1367.

Khan, A. Q., Chattopadhyay, G., Sen, G., Colino, J., Rubtsov, A., Torres, R. M., et al., 2007. Transgenic expression of Bcl-xL or Bcl-2 by murine $\mathrm{B}$ cells enhances the in vivo antipolysaccharide, but not antiprotein, response to intact Streptococcus pneumoniae. The Journal of Immunology, 179(11), 7523-7534.

King, R.J.B., 2000. Cancer Biology, 2nd ed., Pearson Education Limited.

Kubatka, P., Ahlersova E., Ahlers I, Bojkova B., Kalicka K., Adamnekova E., et al., 2002. Variability of Mammary arcinogenesis Induction in Female Sprague-Dawley and Wistar; Hans Rats; the Effect of Seasons. Physiology Research, 51, 663-640.

Kumar Sunil M., Sinha, S., Mittal, S. P., Singh, K., Kadreppa, S., Kamat, R., et $a l, 2010$. Coordinated regulation of p53 apoptotic targets BAX and PUMA by SMAR1 through an identical MAR element. The EMBO Journal, 29(4), 830-842.

Kuo, P.C., L.S. Shi, A. G. Damu, et al., 2003. Cytotoxic and antimalarial $\hat{\mathrm{I}}^{2}-$ carboline alkaloids from the roots of Eurycoma longifolia, Journal of Natural Products, 66(10), 1324-1327.

Mahfudh, N., Pihie, A.H.L., 2008. Eurycomanone Induces Apoptosis Through the Up-Regualation of p53 in Human Cervical Carcinoma Cells. Journal of Cancer Molecules, 4, 109115.

Meiyanto, E., Susilowati, S., Tasminatun, S., Murwanti, R., Sugiyanto, 2007. Efek Kemopreventif ekstrak etanolik Gynura procumbens (Lour), Merr pada karsinogenesis kanker payudara tikus. Majalah Farmasi Indonesia, 18, 154161.

Minotti, G., Menna, P., Salvatorelli, E., Cairo, G., Gianni, L., 2004. Anthracyclines: molecular advances and pharmacologic developments in antitumor activity and cardio toxicity. Pharmacological reviews, 56(2), 185229.

Nepal, N., Talwar, O. P., 2014. Evaluation of AgNoR scores in aspiration cytology smears of breast lesions and their correlation with histopathology. Journal of Pathology of Nepal, 4(8), 649-653.

Niah, R., 2015. Efek Kombinasi Fraksi Etil Asetat Ekstrak Etanol 70\% Akar Pasak Bumi (Eurycoma longifolia Jack) dengan Doxorubicin terhadap Apoptosis Antiproliferasi dan Ekspresi RAS pada sel T47D. Tesis, Fakultas Farmasi Universitas Ahmad Dahlan, Yogyakarta.

Nurani, L. H., 2011. Mekanisme molekuler kemopreventif dan antikanker senyawa aktif akar pasak bumi (Eurycoma longifolia Jack) kajian in vitro pada sel T47D dan in vivo pada kanker payudara pada tikus SD yang diinduksi DMBA. Disertasi, Universitas Gadjah Mada. 
Nurhanan, M.Y, Hawairiah, A., Ilham, M.A., Shukri, M., 2005. Cytotoxic effects of the root extracts of Eurycoma longifolaia Jack. Phytother Res, 19, 994-996.

Rajapaksa, K. S., Sipes, I. G., and Hoyer, P. B., 2007. Involvement of microsomal epoxide hydrolase enzyme in ovotoxicity caused by $7, \quad 12-$ dimethylbenz [a] anthracene. Toxicological sciences, 96(2), 327-334.

Ren, W., 2003. Flavonoids: promising anticancer agents. Medicinal research reviews, 23(4), 519-534.

Rizali, E., E. I. Auerkari, 2003. Teknik pewarnaan silver (AgNOR) sebagai salah satu cara menentukan aktivitas proliferasi sel tumor dan apoptosis. Jurnal Kedokteran Gigi Indonesia 10(3), 41-45.

Shapiro, G.I., J. Harper, J.W., 1999. Anticancer drug targets: cell cycle and checkpoint control. J. Clin Invest, 104(12), 1645-1653.

Sharma, G., Tyagi, A.K., Singh, R.P., Chan, D.C.F., and Agarwal, R., 2004. Synergistic anti-cancer effect of grape seed extract and conventional cytotoxic agent doxorubicin against human breast carcinoma cells. Breast Cancer Research and Treatment, 85:1-12.

Shen, Y., Joachimiak, A., Rosner, M. R., and Tang, W. J., 2006. Structures of human insulin-degrading enzyme reveal a new substrate recognition mechanism. Nature, 443(7113), 870-874.

Shi, Y., Moon, M., Dawood, S., McManus,, B., Liu, P.P., 2011. Mechanisms and Management of Doxorubicin Cardiotoxicity. Herz, 36(4), 296-305.

Smith, L., M. B. Watson, S. L. O'Kane, et al., 2006. The analysis of Doxorubicin resistance in human breast cancer cells using antibody microarrays. Molecular Cancer Therapeutics, 5(8), 2115-2125.
Tannock, I. F., Michael, M., 1998. Measuring health-related quality of life in clinical trials that evaluate the role of chemotherapy in cancer. CMAJ, 158(13), 1727-1734.

Tee, T.T., Y. H. Cheah and L.P.A. Hawariah, 2006. F16 a fraction from Eurycoma longifolia Jack extract, induces apoptosis via a caspase-9independentmanner in MCF-7 cells. Anticancer research, 27(5A), 34253430.

Tee, T.T., Azimahtol, H.L.P., 2005. Induction ofapoptosis by Eurycoma longifolia Jack extract. Anticancer Research, 25, 2205-2214

Tjindarbumi, D., Mangunkusumo, R., 2002. Cancer in Indonesia, present and future. Jpn J Clin Oncol, 32 (Supplement 1), 17-21.

Wattanpitayakul, S.K., Chlarojmontri, L., Herunsalee, A., Charuchongkolwongse, S., Niumsakul, S., and Bauer, J.A., 2005. Screening of Antioxidants from Medicinal Plants for Cardioprotective Effect against doxorubicin. Toxicity, Basic and Clinical Pharmacology and Toxicology, 96, 80.

Yuliarto, S., Kusuma, HMS Chandra., Widjajanto, Edi., 2013. Peningkatan Ekspresi Interleukin (IL)-4 Berhubungan dengan Penurunan Bax dan Apoptosis Limfosit pada Bronkiolus dan Paru Mencit Asma. Jurnal Kedokteran Brawijaya, 25 (3), 100-110.

Zhang, W., Liu, H.T., 2002. MAPK signal pathways in regulation of cell proliferation in mammalian cell. Cell Research, 12, 9-8.

Zhivotovsky, B., Orrenius, S., 2006. Carcinogenesis and apoptosis: paradigms and paradoxes. Carcinogenesis, 27(10), 1939-1945. 